\title{
Marketing Challenges and Strategies for Internationalization of Service Firms
}

\author{
Hamidreza Radmanesh ${ }^{1}$ \\ ${ }^{1}$ Linköping University, Linkoping, Sweden \\ Correspondence: Hamidreza Radmanesh, Linköping University, Linkoping, Sweden.
}

Received: September 9, 2018

Accepted: October 3, 2018

Online Published: October 19, 2018

doi:10.20849/iref.v2i2.493

URL: https://doi.org/10.20849/iref.v2i2.493

\begin{abstract}
This study aims to look back on literature related to internationalization process of service firms. In this regards, the emphasis is on marketing challenges and the target (and motivator of this study) is identification of the suitable strategy to succeed in facing these challenges. In the other word challenges in the path of internationalization of the service firms are identified and relevant entry mode and strategies to cope with those challenges are presented.
\end{abstract}

Keywords: services marketing, internationalization of services, marketing strategy, international marketing, entry mode selection, internationalization process

\section{Introduction}

In late decades, according to opening of new markets around the world and the shift in competition from domestic market to a global level, firms have attempted to seek after global or international marketing strategies.

Internationalization of a firm can be considered as a process that enables the firm to work in foreign markets as well as the domestic market (Heino, 2008). Internationalization processes can be incremental (regular long-term) or born global (short-term irregular non-incremental) (Hadjikhani, 2014).

In internationalization, how to make services available in foreign markets appeared to be an interesting inquiry and an encouraging method for moving forward service-focused international-marketing understanding.

The service firms are growing over national borders. It should be mentioned that the wave of Internationalization of services has been posterior in comparison to product sector and the literature in the 70's declares that the general writing on international marketing and internationalization was mostly product focused (Grönroos, 2016).

\section{A Theoretical Lens}

A) Internationalization process of a general firm

In past decades, many literature discuss about internationalization process of a firm.

The proposed model (Uppsala model) by Johanson and Vahlne (2009) focuses on items in Figure 1.

According to Uppsala model (U-M), the basic mechanism of internationalization is based on two aspects:

$>$ State

$>$ Change

Welch and Luostarinen (1998) clarified that the internationalization is, "the process increasing involvement in international operations". Calof and Beamish (1995) define internationalization as, "the process of adapting firms' operations (strategy, structure, resource, etc.) to international environments".

In 2009, Johanson and Vahlne revisited their initial model (U-M). So, for justification of Revisited Uppsala model (RU-M) they declare that,

"The change mechanisms in the revised model are essentially the same as those in the original version, although we add trust-building and knowledge creation, the latter to recognize the fact that new knowledge is developed in relationships." 


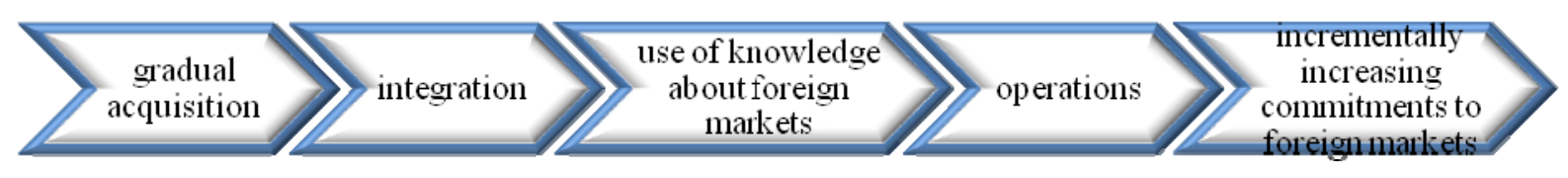

Figure 1. Uppsala model focusses

B) Internationalization process of service firms

In previous part, some models such as U-M and RU-M for internationalization process for a general firm introduced. It should be mentioned that, although these models are for general firm but they pay more attention for product sector. So in this part we put our emphasis on service firms and some discussion on usability of these models on service sector will be brought up.

Some researchers have inquired whether the Uppsala model would be generalizable to service firms. It seems for service firms U-M was valid more than two decades. For example, Sacramento et al. (2002) show that this model is applicable for service sector too.

But some years later, Carneiro et al. (2008) proposed some hypotheses for service sector in terms of their entry mode and what the performance meaning would be attended to be. These hypotheses are opposite of the U-M predictions.

In another perspective, Hollensen (2001) classified main aspects of a firm's internationalization process as four steps. These steps utilized by Lommelen and Matthyssens (2005) for service firms (Figure 4).

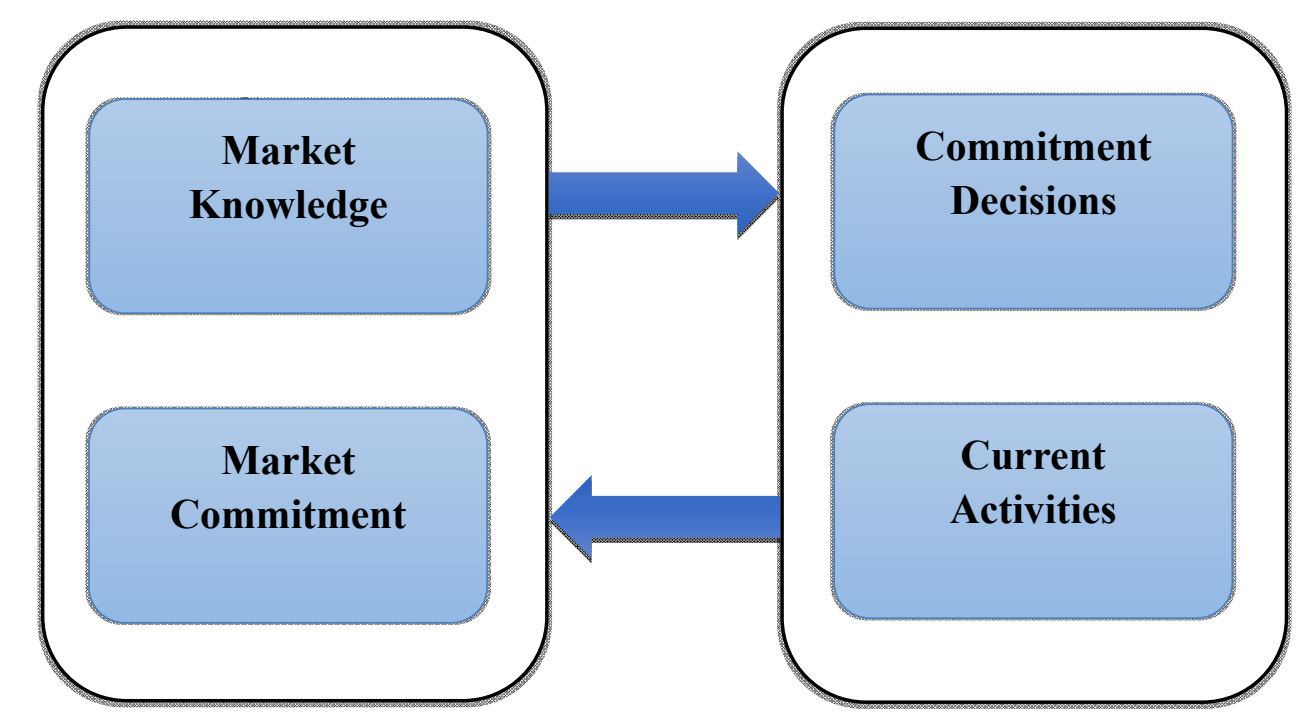

Figure 2. Mechanism of internationalization (Uppsala model) 


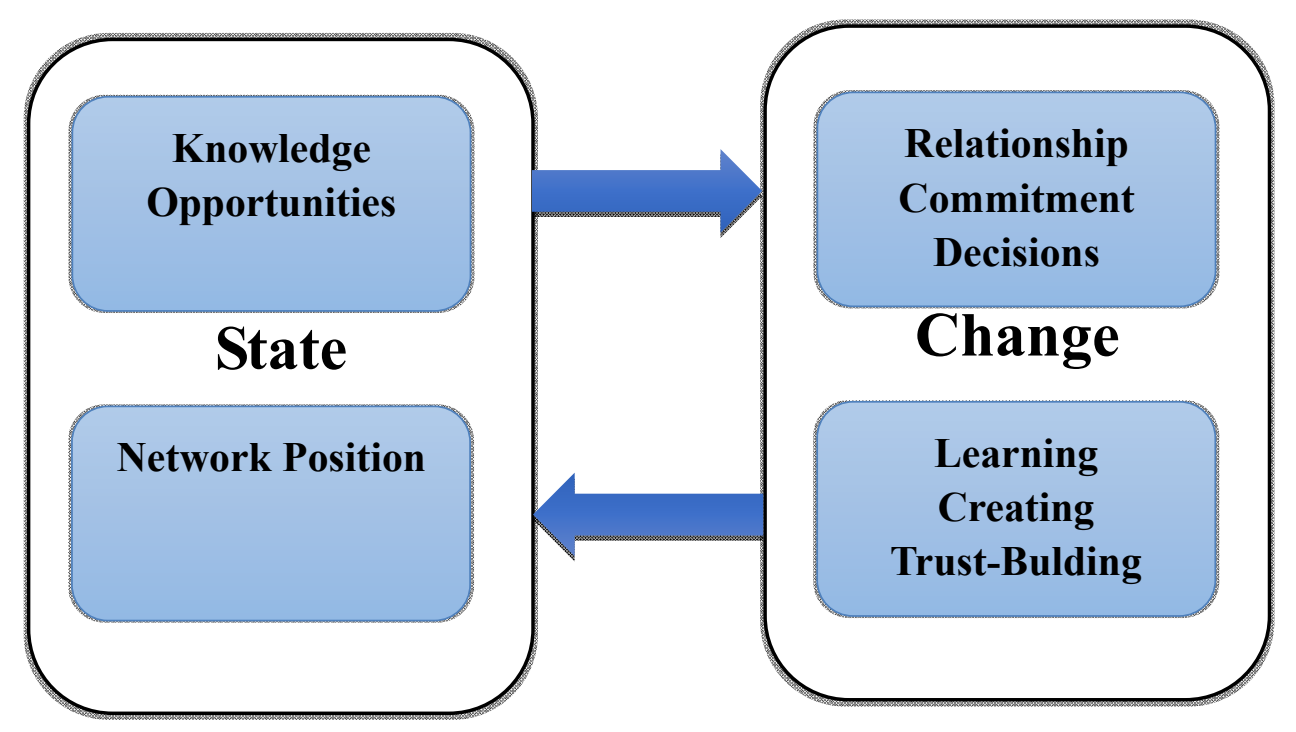

Figure 3. Revisited uppsala model (Johanson \& Vahlne, 2009)

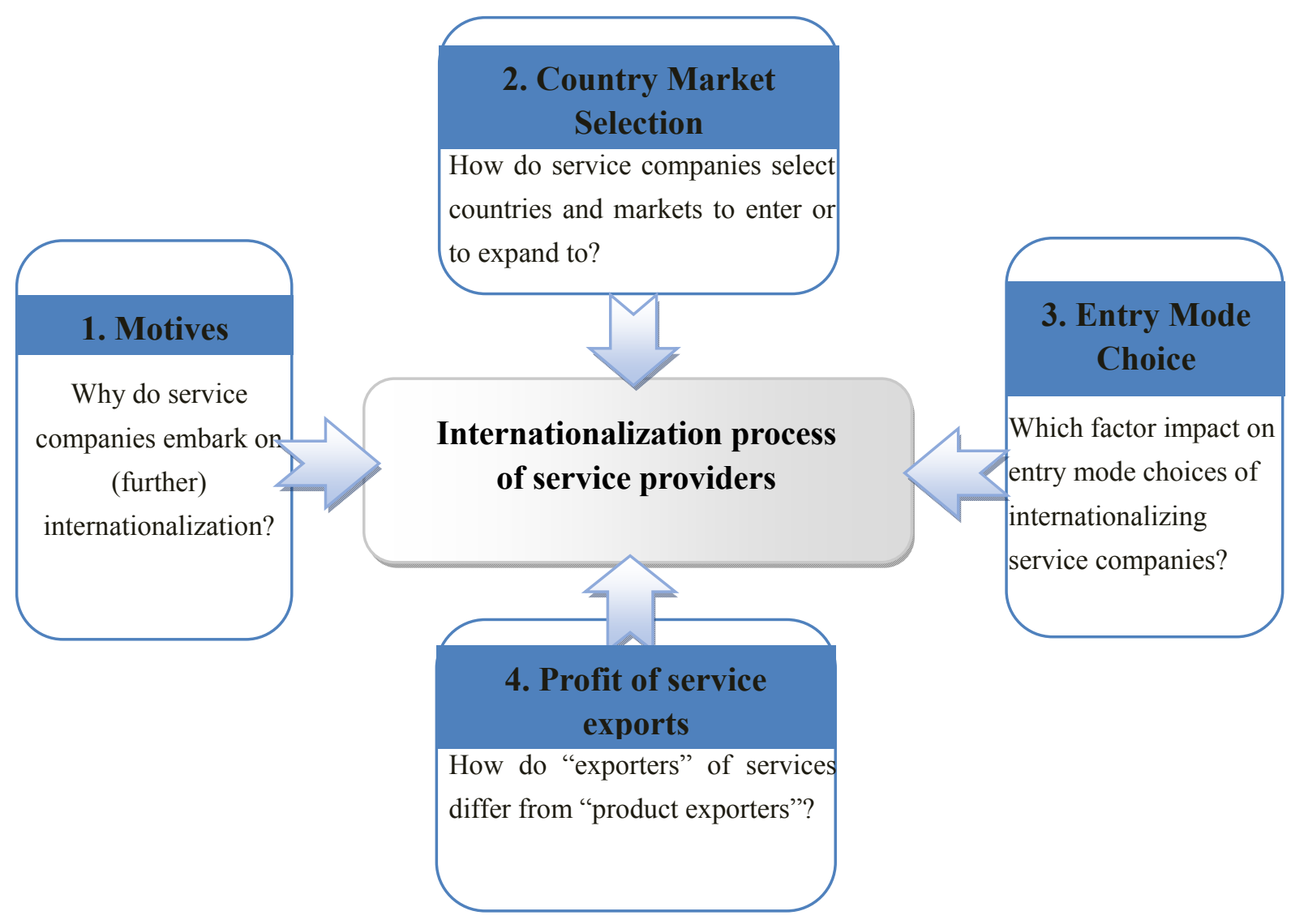

Figure 4. Internationalization process for service firms

The internationalization process is affect by the kind of service. The U-M doesn't describe internationalization for non-exportable services (Menzies \& Orr, 2013). 
C) The internationalization challenge

An internationalization strategy usually is more risky for service sector than product. One explanation behind this is that in many services the producer and the production facilities are part of the service, which requires that the firm has high control of its resources. Also one of the challenges in the path of internationalization is analyzation. The company should analyze the attractiveness of the market and the company itself (Heino, 2008).

Internationalization is along with changes in structure and even there are some records of organizational changes occurring as foundation of new departments due to Internationalization of the firm (Garri \& Konstantopoulos, 2013).

Carrying out the business operation in the new market is another challenge for Internationalization. The correct entry mode and excellent positioning strategy can lead to overcome to this challenge (Heino, 2008).

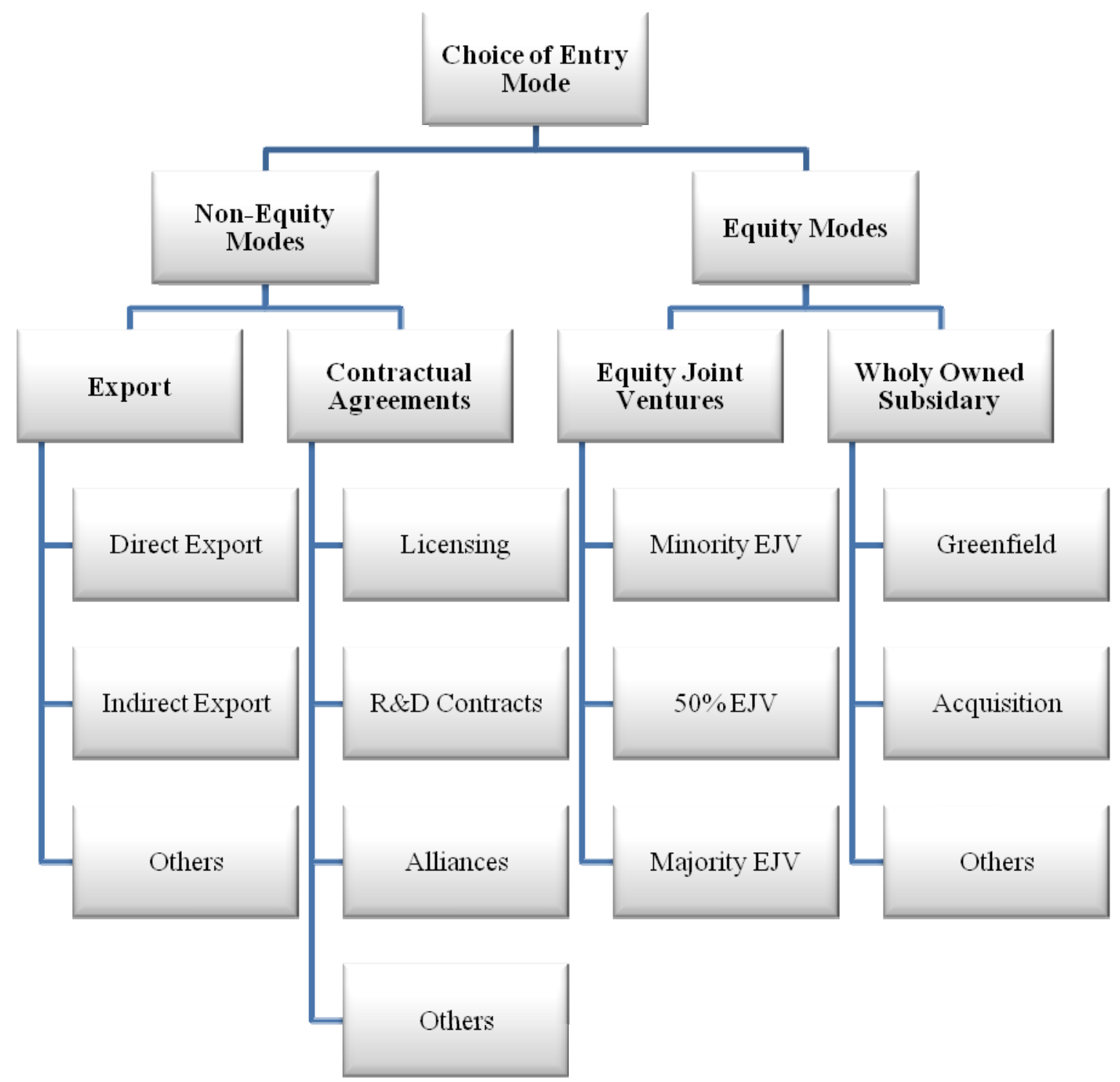

Figure 5. A hierarchical model of choice of entry mode

D) Entry mode and strategies

Entry mode selection is considered as an appropriate way for businesses to enter foreign markets so as to operate 
their international businesses by utilizing their advantages (Root, 1998). In other words, entry mode has putted stress on the primary choice for performing international activities (Rezende, 2003).

For firms, entry mode choice is an important strategic decision with long-term outcome for competitive advantage and performance. Foreign market entry involves exporting, contractual entry (licensing and franchising), joint ventures, green field investments and acquisitions. In other classification, entry modes can be considered as two categories of equity based modes (wholly owned operations and equity joint ventures) and non-equity based modes (contractual agreements and export) (Pan \& David, 2000) (See Figure 5).

Literature on defining initial mode of operation in foreign markets for service firms is divided to two contradictory consequences. Findings from one type of researches indicate that entry mode factors for manufacturing firms are generalizable to service firms. Findings from another type of researches having conflicts with the first view. The authors adapt the two views by means of a classification scheme that allows some services to be grouped with manufactured goods in terms of entry mode choice (Ekeledo \& Sivakumar, 1998).

Lommelen and Matthyssens (2005), listed major factors for entry mode in service firms (Table 1).

In another study, general entry modes for service firms going into foreign markets are identified: client-following mode, market-seeking mode; and electronic marketing and e-commerce mode (Hadjikhani, 2014; Sacramento et al., 2002). For internationalizing services five main strategies can be identified: (1) direct export; (2) systems export; (3) direct entry; (4) indirect entry; and (5) electronic marketing (Grönroos, 2016; Grönroos, 1999).

\section{Conclusion}

In this research literatures from 1977 are considered to study. A service firm which wants its services come into international market has to discover how its services accessible in the foreign target market. Along the way of internationalization, a company faces to some challenges: the firm should precisely analyze the market and the company itself, also structure and operation should be well-organized. Precisely selection of entry mode and positioning strategy leads to succeed in facing these challenges.

\section{References}

Calof, J. L., \& Beamish, P. W. (1995). Adapting to foreign markets: Explaining internationalization. International business review, 4(2), 115-131. https://doi.org/10.1016/0969-5931(95)00001-G

Carneiro, J., Rocha, A. D., \& Silva, J. F. D. (2008). Challenging the Uppsala internationalization model: a contingent approach to the internationalization of services. BAR-Brazilian Administration Review, 5(2), 85-103. https://doi.org/10.1590/S1807-76922008000200002

Ekeledo, I., \& Sivakumar, K. (1998). Foreign market entry mode choice of service firms: a contingency perspective. Journal of the academy of marketing science, 26(4), 274-292. https://doi.org/10.1177/0092070398264002

Garri, M., \& Konstantopoulos, N. (2013). The management of internationalization: structural modifications and inter-organizational significance. Economics and Management: Current Issues and Perspectives Journal, 29(1), 126-135.

Grönroos, C. (1999). Internationalization strategies for services. Journal of services marketing, 13(4/5), 290-297. https://doi.org/10.1108/08876049910282547

Grönroos, C. (2016). Internationalization strategies for services: a retrospective. Journal of Services Marketing, 30(2), 129-132. https://doi.org/10.1108/JSM-11-2015-0354

Hadjikhani, A., Hadjikhani, A. I., \& Thilenius, P. (2014). The internationalization process model: a proposed view of firms' regular incremental and irregular non-incremental behaviour. International Business Review, 23(1), 155-168. https://doi.org/10.1016/j.ibusrev.2013.03.005

Heino, J. (2008). Challenges of internationalization.

Hollensen, S. (2001). Global Marketing: A market-responsive approach.

Johanson, J., \& Vahlne, J. E. (2009). The Uppsala internationalization process model revisited: From liability of foreignness to liability of outsidership. Journal of international business studies, 40(9), 1411-1431. https://doi.org/10.1057/jibs.2009.24

Lommelen, T., \& Matthyssens, P. (2005). The internationalization process of service providers: a literature review. In Research on international service marketing: a state of the art (pp. 95-117). Emerald Group Publishing Limited. 
Menzies, J. L., \& Orr, S. (2013). The Services Internationalization Process: An Exploratory Investigation of Australian Service Company Internationalization to China. Journal of Asia-Pacific Business, 14(4), $287-311$. https://doi.org/10.1080/10599231.2013.795785

Pan, Y., \& David, K. T. (2000). The hierarchical model of market entry modes. Journal of international business studies, 31(4), 535-554. https://doi.org/10.1057/palgrave.jibs.8490921

Rezende, S. F. L. (2003). Internationalisation processes: an analytical framework. Revista de Administração Contemporânea, 7(2), 137-156. https://doi.org/10.1590/S1415-65552003000200008

Root, F. R. (1998). Entry strategies for international markets. San Francisco, CA: Jossey-Bass.

Sacramento, I., Almeida, V. M. C. D., \& Silva, M. S. M. D. (2002). The internationalization process of services firms: a two-case study in Brazil. Latin American Business Review, 3(2), $43-64$. https://doi.org/10.1300/J140v03n02_03

Welch, L. S., \& Luostarinen, R. (1988). Internationalization: Evolution of a concept. The Internationalization of the firm, 14, 83-98. https://doi.org/10.1177/030630708801400203

\section{Copyrights}

Copyright for this article is retained by the author(s), with first publication rights granted to the journal.

This is an open-access article distributed under the terms and conditions of the Creative Commons Attribution license (http://creativecommons.org/licenses/by/4.0/). 